CURRENT RESEARCH JOURNAL OF PHILOLOGICAL SCIENCES

(ISSN -2767-3758)

VOLUME 03 ISSUE 01 Pages: 108-110

SJIF IMPACT FACTOR (2021: 5 . 823)

OCLC - 1242423883 METADATA IF - 6.925
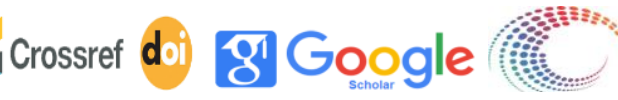

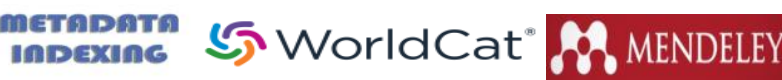

Publisher: Master Journals

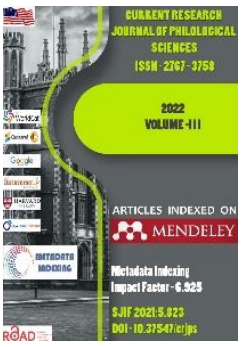

Journal Website: https://masterjournals. com/index.php/crips

Copyright: Original content from this work may be used under the terms of the creative commons attributes 4.0 licence.
Research Article

\section{CURRENT STATE OF TRANSLATION}

Submission Date: January 11, 2022, Accepted Date: January 21, 2022, Published Date: January 31, 2022

Crossref doi: https://doi.org/10.37547/philological-crjps-03-01-18

\section{Kamalova Gulnora Mahamatjonovna}

Teacher Of The Russian Language And Literature Of The Professional School Of The City Of Kuvasay, Uzbekistan

\title{
ABSTRACT
}

This article talks about the modern state of translation, as well as the laws of translation. The relevance of this topic is that the translation in its development has passed several stages, but currently preference is given to informative translation, in which the features of the individual author style are not so significant.

\section{KEYWORDS}

Object difference, translation, translation in own development, development of information technologies, advertising texts.

\section{INTRODUCTION}

The current position of translation theory is characterized not only by an ongoing selection of the laws of translation of the work, but also by a constant refinement of both the subject and the object of this science.

The distinction between the object and the subject of science, or a certain scientific study, is not carried out constantly. In terms of the general theory of cognition, the opposition of the subject and the object relative.

The relevance of the topic is that the translation in its development has passed a couple of steps, but currently preference is given to informative translation, and the features of the individual author 


\section{CURRENT RESEARCH JOURNAL OF PHILOLOGICAL SCIENCES}

(ISSN -2767-3758)

VOLUME 03 ISSUE 01 Pages: 108-110

SJIF IMPACT FACTOR (2021: 5 . 823)

OCLC - 1242423883 METADATA IF - 6.925

\section{Crossref

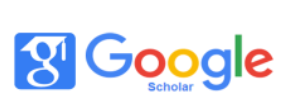

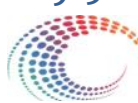

metapata

5. WorldCat fి̂ MENDELEY

Publisher: Master Journals

style are not so significant. Also, with the development of information technologies, computer programs have appeared, to facilitate translation, many applications and more, we should know the disadvantages and advantages of this type of translation. All these changes are related to marketing texts, which in their own importance go to the highest place. At first, translation made the most important social function, making inter-language communication of people likely. The dissemination of translations has allowed people wide access to the cultural achievements of other peoples, made cooperation and mutual enrichment of literature and cultures likely.

Whatever the case, when a text written in one language is re-expressed by means of another language, we call translation. With all this, the term "text" is understood as widely as possible: at least some oral expression and written work from annotation to refrigerator to novel. But there are also limitations: in our reasoning, we will be limited only to verbal texts in living human languages. If we assume that the language is a code of its own kind, that is, the random designation of objects and phenomena of reality using conditional symbols, then the translation can be called transcoding, since any of the conditional symbols is replaced when translated by a sign of another sign system. Translation is a complex multifaceted phenomenon, some aspects of which can be the subject of study of different sciences. Translation is a difficult multifaceted phenomenon, some of the nuances of which can be the subject of analysis of various sciences.

Within the framework of translation studies, mental, literary, ethnographic and other also the history of translation work in one country or another or in States. Currently, the main translation function is informative or communicative, so translation is a means of ensuring the possibility of communication (communication) between people who speak different languages. Therefore, for the theory of translation, data of communicative linguistics on the features of the process of speech communication, the specifics of direct and indirect speech acts, the ratio of expressed and implied meaning in the statement and text, the influence of the context and situation of communication on the understanding of the text, other factors determining the communicative behavior of a person are of particular importance.

The translation in its development has passed several stages. There was a translation and verbatim (mainly it affected the translation of bibles), there was a period when the authors received a new work when translating the original, at the same time the individual-author style is not so significant. It is known that a complete identity between the original and the translation is not possible. The linguistic originality of any text, the orientation of its content to a certain language team, which has only its inherent "background" knowledge and cultural and historical features, cannot be "recreated" with absolute completeness in another language. The lack of identity does not prevent translation from performing the same communicative functions for which the original text was created. Nowadays, when translating, authors often use realities ("everyday and specific words and turns are indicated that do not have an equivalent in everyday life, and, therefore, in the languages of other countries"), especially when translating from Brazilian, Spanish and other languages whose culture of peoples is not yet fully known to us. For example, when translating the book of the Portuguese writer Jorge Amado, the translator uses realities, but at the end of the work gives explanations: for example, "Craftsmen make ridges, 


\section{CURRENT RESEARCH JOURNAL OF PHILOLOGICAL SCIENCES}

(ISSN -2767-3758)

VOLUME 03 ISSUE 01 Pages: 108-110

SJIF IMPACT FACTOR (2021: 5 . 823)

OCLC - 1242423883 METADATA IF - 6.925
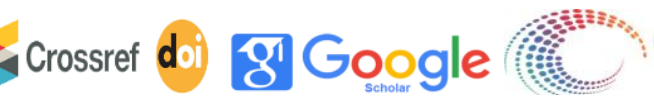

meTaDaTh

5. WorldCat

Publisher: Master Journals

rings, cups for kashas and much more from them." Kashasa - sugar cane vodka; behind him came from afar to invite to christening, wedding or velorio: no one better than him could come up with a health resort in honor of the newlyweds or tell a story at a night vigil that would make even the dead cry or laugh. - Velorio is a night vigil at the coffin. " Speaking about the important role of translation, we immediately mentioned its "overcoming" function. After all, he helps people get closer, understand each other. It has long been clear that translation helps to overcome language and cultural barriers. Let's try to figure out where these barriers come from and what it is to overcome them.

Thus, language barriers exist because humanity is historically multilingual. According to modern researchers, the number of living languages in the world ranges from 2500 to 50003 . There are more than a thousand Indian languages, about a thousand African languages; only in the islands of New Guinea there are more than 700 different languages. True, the main part of languages are languages with a very small number of speakers (some of them are spoken by only 100 to 1000 people; a characteristic example is the Mansi language in Russia: about 150 speakers). Languages spoken by $95 \%$ of the world's population are less than 100. Nevertheless, if we at least hypothetically imagine that every resident of the planet may have the need to communicate with representatives of each of the languages of the world, then the number of language barriers will be unusually high.

\section{REFERENCES}

1. Fedorov A.V. Introduction to translation theory. M.: Vysh. school, 1953. - $292 \mathrm{sec}$.

2. Komissarov V.N. Modern translation. - M.: ETS Publishing House, 2004. - 424 S.
3. Left Jiri. The art of translation. - M.: Publishing house "PROGRESS," 1974. - 395 s.

4. Minyar-Beloruchev R.K. General theory of translation and interpretation. - M.: Military building, 1980. - $237 \mathrm{~s}$.

5. Robinson Douglas. How to become a translator. Introduction to translation theory and practice. M.: KUDITZ-IMAGE, 2005. - $304 \mathrm{~S}$

6. Sultanova S.R. GENERAL THEORY OF LINGUISTIC VARIATION. EPRA International Journal of Research \& Development, 2021 